Note

\title{
Effects of Angiotensin I-Converting Enzyme Inhibitor from Ashitaba (Angelica keiskei) on Blood Pressure of Spontaneously Hypertensive Rats
}

\author{
Emiko Shimizu, Atsumi Hayashi, Rumiko Takahashi, \\ Yasuo Aoyagi, ${ }^{1}$ Tetsuo MuraKami ${ }^{2}$ \\ and Koichi КІмото* \\ Department of Nutrition, Tokyo Kasei University, \\ Itabashi-ku, Tokyo 173-8602, Japan \\ ${ }^{1}$ Department of Food Chemistry, Kagawa Nutrition Junior College, \\ Toshima-ku, Tokyo 170-8481, Japan \\ ${ }^{2}$ Department of Food Science and Nutrition, \\ Faculty of Agriculture, Kinki University, \\ Nara, Nara 631-0052, Japan
}

(Received June 3, 1998)

Summary The inhibitory activity of angiotensin I-converting enzyme (ACE) was extracted with $80 \%$ ethanol from the leaves of Ashitaba (Angelica keiskei). The present ACE inhibitor was fractionated and separated with various chromatographies. The antihypertensive effects of the sample ( $\mathrm{G}$ fraction) from Ashitaba on spontaneously hypertensive rats (SHR) were observed by long-term administration for $10 \mathrm{wk}$. Another sample (S fraction) from Ashitaba also had antihypertensive effects after a single intravenous administration to SHR. The sample was further purified by using several chromatographies. The ACE inhibitor fraction was characterized as follows: no significant absorbance, a zwitterion, a water-soluble substance and a positive ninhydrin reaction. According to a mass spectrum analysis, the molecular weight of the ACE inhibitor was determined to be 303 and $\mathrm{Na}$-salt ions of carboxyl groups were detected. The ACE inhibitor from Ashitaba contained in the anti-hypertensive fraction was speculated to be very similar to authentic nicotianamine based on a comparative study of inhibitory activity, mass spectrum analysis and thin-layer chromatographies.

Key Words ACE inhibitor, Ashitaba (Angelica keiskei), SHR, blood pressure, antihypertensive factor

* To whom correspondence should be addressed. 
Hypertension may induce cerebral apoplexy and cardiovascular disease. Over $90 \%$ of the hypertension cases are diagnosed as essential hypertension. The renin-angiotensin (R-A) system plays an important role in essential hypertension. Angiotensinogen is cleaved by an aspartyl proteinase renin (EC 3.4.23.15) to release decapeptide angiotensin I (AI). Angiotensin I-converting enzyme (ACE; EC 3.4.15.1) cleaves dipeptides from the free $\mathrm{COOH}$-terminal of $\mathrm{AI}$ and produces angiotensin II (AII), which has some physiological actions, vasoconstrictive and aldosterone secretory (1). Therefore, the inhibition of ACE can reduce blood pressure. ACE inhibitors such as captopril and enalapril have been used as antihypertensive drugs (2).

In recent years, many ACE inhibitory peptides from food protein sources have been isolated and reported, such as casein (3), tuna (4) and bonito (5). There have been a few reports about non-peptidyl ACE inhibitors, polyphenols (6) and nicotianamine (7). Ashitaba (Angelica keiskei) is a well-known vegetable and a wild plant that grows mainly on the Izu Islands, Japan (8). It contains highly nutritional components and is speculated to have various physiological effects on health $(9,10)$.

In this paper, the effects of the ACE inhibitor from Ashitaba on the blood pressure of SHR was studied, and the ACE inhibitor was purified and characterized.

\section{Materials and methods}

Materials. Ashitaba was obtained from Saitama Prefecture and Hachijyoujima Island Agricultural Corp. ACE from rabbit lung acetone powder was purchased from Sigma Chemical Co. (U.S.A.). Hippuryl-L-histidyl-L-leucine (Hip-His-Leu) was from the Peptide Institute (Osaka, Japan). TLC (silica gel $60 \mathrm{~F}_{254}$ ) was from Merck Co. Dowex 50W-X8 and Dowex 1-X4 were obtained from Dow Chemical Co. (U.S.A.). Sephadex G-10 and G-25 were from Pharmacia Fine Chemicals. The Asahipak ODP-50 column was from Asahi Chemical Industry (Tokyo, Japan). CE-2 was purchased from CLEA Japan, Inc. Other chemicals were from Wako Co. (Japan). Authentic nicotianamine was kindly supplied by Kikkoman Co. (Japan).

Assay method of ACE inhibitory activity. The activity of the ACE inhibitor was assayed by the modified method of Cushman and Cheung (11). The reaction mixture was as follows: $500 \mu \mathrm{L}$ of $7 \mathrm{~mm}$ Hip-His-Leu in $200 \mathrm{~mm}$ borate buffer $(\mathrm{pH}$ 8.3), $400 \mu \mathrm{L}$ of $2.0 \mathrm{M} \mathrm{NaCl}, 40 \mu \mathrm{L}$ of distilled water and $30 \mu \mathrm{L}$ of inhibitor. ACE activity was evaluated with $153.6 \mathrm{mU} / \mathrm{mL}$. After incubation at $37^{\circ} \mathrm{C}$ for $30 \mathrm{~min}$, the reaction was stopped by adding $500 \mu \mathrm{L}$ of $1 \mathrm{M} \mathrm{HCl}$. The hippuric acid released by the action of ACE was extracted with $3 \mathrm{~mL}$ of ethyl acetate. After centrifugation for $15 \mathrm{~min}$ at $3,000 \mathrm{rpm}, 2 \mathrm{~mL}$ of the upper layer was dried for $3 \mathrm{~h}$ at $60^{\circ} \mathrm{C}$ in vacuo by a speed back concentrator (TAITEC, VC-960). The residue was dissolved in $1 \mathrm{~mL}$ of distilled water, and the absorbance was measured at $228 \mathrm{~nm}$. The inhibitory activity was calculated by the following formula: Residual activity $(\%)=($ Sample Blank $) /($ Control - Blank $) \times 100$; Inhibitory activity $(\%)=100$-Residual activity. One unit of ACE activity is defined as the amount catalyzing the formation of $1 \mu \mathrm{mol}$ 
of hippuric acid from Hip-His-Leu in $1 \mathrm{~min}$ at $37^{\circ} \mathrm{C}$. The concentration of ACE inhibitors needed to inhibit $50 \%$ of $\mathrm{ACE}$ activity was defined as the $\mathrm{IC}_{50}$ value under those conditions.

The sample preparation for long-term and single administration. Inhibitory activity was observed in the leaves but not the stems of Ashitaba, and the ACE inhibitor could be extracted with $80 \%$ ethanol but not with $100 \%$ ethanol. Approximately $7 \mathrm{~kg}$ of lyophilized Ashitaba leaves was homogenized and extracted twice with 10 volumes of $80 \%$ ethanol. After treatment with activated carbon and ether, ACE inhibitory activity was purified by ion exchange chromatographies on Amberlite IR120-B (column was previously prepared as $\mathrm{H}^{+}$type and the ACE inhibitor was eluted with $2 \mathrm{~N} \mathrm{NH}_{4} \mathrm{OH}$ ), Dowex $50 \mathrm{~W}-\mathrm{X} 8$ (column was previously prepared as $\mathrm{H}^{+}$type and the ACE inhibitor was eluted with $0.5 \mathrm{M} \mathrm{NH}_{4} \mathrm{OH}$ ), Dowex 1-X4 (column was previously prepared as $\mathrm{CH}_{3} \mathrm{COO}^{-}$type and the ACE inhibitor was eluted with $0.05 \mathrm{M} \mathrm{CH}_{3} \mathrm{COOH}$ ), and gel filtrations on Sephadex G-10 and G-25. This ACE inhibitor fraction was termed the $\mathrm{G}$ fraction $\left(\mathrm{IC}_{50}\right.$ value $=4.1 \mu \mathrm{g} / \mathrm{mL}$ ) for long-term administration.

The $G$ fraction was further purified by silica gel chromatography with a mixture of $n$-propanol-ammonia solution $(3: 1, \mathrm{v} / \mathrm{v})$. The ACE inhibitory fraction $\left(\mathrm{IC}_{50}\right.$ value $=2.7 \mu \mathrm{g} / \mathrm{mL}$ ) was obtained and called the $\mathrm{S}$ fraction for single administration to SHR.

Experimental animals and measurement of blood pressure.

1. Long-term administration: Male spontaneously hypertensive rats (SHR) were purchased from Charles River Japan, Inc. Nineteen male SHR were divided into three groups at $5 \mathrm{wk}$ of age. The $\mathrm{G}$ fraction $\left(\mathrm{IC}_{50}=4.1 \mu \mathrm{g} / \mathrm{mL}\right)$ was mixed with drinking water at $21.8 \mathrm{mg} / \mathrm{kg} / \mathrm{d}$, and captopril was used at $0.3 \mathrm{mg} / \mathrm{kg} / \mathrm{d}$. The diet (CE-2) was given ad libitum for $10 \mathrm{wk}$. Rats were bred in a room with the temperature set at $21 \pm 2{ }^{\circ} \mathrm{C}$, humidity at $55 \pm 10 \%$ and lighting for $12 \mathrm{~h}$ daily (light from 06:00 to 18:00). During the experimental period, blood pressure was measured once a week, and body weight, food intake and drinking volume were measured every day. Systolic blood pressure was measured without anesthesia by the tail-cuff method (PB98A, Softron).

2. Single administration: A male SHR, weighing $293 \mathrm{~g}$, was anesthetized by an intraperitoneal injection of nembutal. Polyethylene cannulas were inserted into the femoral artery to monitor blood pressure and into the jugular vein to inject the test agents. The arterial blood pressure was measured by a pressure transducer connected to the arterial cannula. The $\mathrm{S}$ fraction $\left(\mathrm{IC}_{50}=2.7 \mu \mathrm{g} / \mathrm{mL}, 5.1\right.$ and $13.1 \mathrm{mg} / \mathrm{kg}$ ) and captopril $(44.4 \mu \mathrm{g} / \mathrm{kg})$ were dissolved in physiological saline and injected into the carotid vein.

Statistical analysis. The experimental data are shown as the mean \pm standard deviation. After the variance of values to be compared was assayed, the results were analyzed by Student's $t$-test or Welch's $t$-test to determine the significance of difference. $p<0.05$ was defined as being significant. 

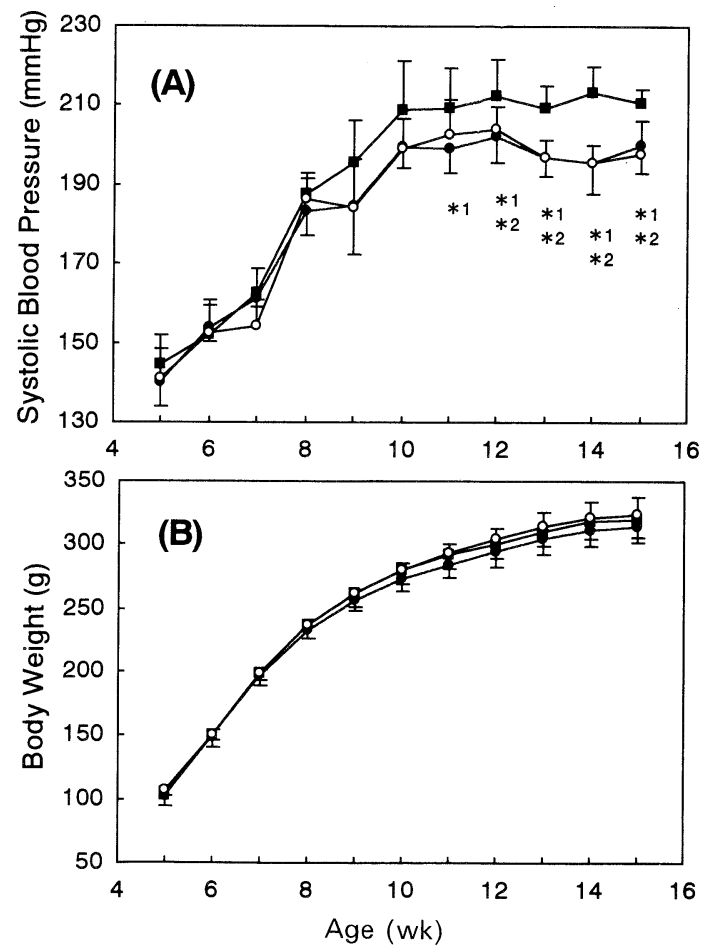

Fig. 1. Effects of long-term administration of the $\mathrm{G}$ fraction and captopril on the blood pressure (A) and body weight (B) of SHR. $\mathbf{a}$, control group; $\mathbf{O}, \mathrm{G}$ fraction-treated group $\left(\mathrm{IC}_{50}=4.1 \mu \mathrm{g} / \mathrm{mL}, 21.8 \mathrm{mg} / \mathrm{kg} / \mathrm{d}\right) ; \bigcirc$, captopril-treated group $\left(\mathrm{IC}_{50}=0.1 \mu \mathrm{g} / \mathrm{mL}, 0.3 \mathrm{mg} / \mathrm{kg} / \mathrm{d}\right)$. The values are expressed as the mean $\pm \mathrm{SD}$. The vertical bars indicate the SEM. * $1, p<0.05$ for differences between groups' control and the $\mathrm{G}$ fraction; *2, $p<0.05$ for differences between groups' control and captopril.

\section{Results and discussion}

Effects of long-term administration of the G fraction from Ashitaba and captopril on $S H R$. The $\mathrm{G}$ fraction $\left(\mathrm{IC}_{50}\right.$ value $\left.=4.1 \mu \mathrm{g} / \mathrm{mL}\right)$, which was used for long-term experiments, was prepared as described in Materials and Methods and contained high ACE inhibitory activity from Ashitaba. Figure 1 shows the effects of the G fraction $(21.8 \mathrm{mg} / \mathrm{kg} / \mathrm{d})$ and captopril $(0.3 \mathrm{mg} / \mathrm{d} / \mathrm{kg})$ on the blood pressure and body weight of SHR. The blood pressure of the $\mathrm{G}$ fraction-treated group was $200 \pm 7.3 \mathrm{mmHg}(n=7)$ at the end of $10 \mathrm{wk}$ of administration. The blood pressure of the control group was $211 \pm 3.7 \mathrm{mmHg}(n=7)$, and that of the captopril-treated group was $198 \pm 8.1 \mathrm{mmHg}(n=5)$. The blood pressure of the $\mathrm{G}$ fraction-treated group was significantly lower than that of the control group from the eleventh to fifteenth weeks, and that of the captopril treated-group was also significantly lower than that of the control group $(p<0.05)$ from the twelfth to fifteenth weeks.

Averages of body weight did not show any difference in these groups. Averages of food intake and water consumed, ratios of organ weights, and serum lipid levels 


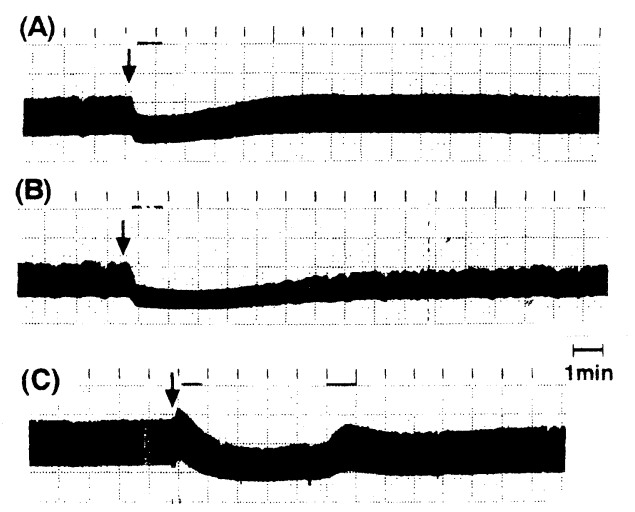

Fig. 2. Effects of a single administration of the $\mathrm{S}$ fraction on the blood pressure of SHR. The $\mathrm{S}$ fraction $\left(\mathrm{IC}_{50}=2.7 \mu \mathrm{g} / \mathrm{mL}\right.$ ) and captopril were given intravenously. (A) $\mathrm{S}$ fraction $(5.1 \mathrm{mg} / \mathrm{kg})$; (B) S fraction $(13.1 \mathrm{mg} / \mathrm{kg})$; (C) captopril $(44.4 \mu \mathrm{g} / \mathrm{kg})$.

of SHR also indicated no difference among them (data are not shown).

Effects of single administration of the $S$ fraction from Ashitaba and captopril on $S H R$. The $\mathrm{S}$ fraction $\left(\mathrm{IC}_{50}\right.$ value $\left.=2.7 \mu \mathrm{g} / \mathrm{mL}\right)$ was used for single administration. It was obtained as described in Materials and Methods, and contained a high concentration of ACE inhibitor from Ashitaba. Figure 2 shows the time course of the effects of a single intravenous injection of $\mathrm{S}$ fraction on the blood pressure of SHR, 11 wk of age. The blood pressure was monitored from the artery with a blood pressure transducer connected to a recorder. This figure showed that the $\mathrm{S}$ fraction decreased blood pressure and dose-dependent activity $(\mathrm{A}, 5.1 \mathrm{mg} / \mathrm{kg}$; and $\mathrm{B}, 13.1 \mathrm{mg} / \mathrm{kg}$ ).

Purification and characterization of the ACE inhibitor from Ashitaba leaves. The $\mathrm{S}$ fraction was further purified by thin-layer chromatography (TLC) and reverse-phase high-performance liquid chromatography (Hitachi HPLC system). After development by TLC with a mixture of $n$-propanol- $29 \%$ ammonia solution $(7: 3, v / v)$, some fractions were carefully scraped loose with a narrow metal spatula and then extracted with $65 \%$ ethanol-1\% ammonia solution. ACE inhibitory activity was detected in only one fraction under cystine (data are not shown). The ACE inhibitor was then applied to an ODP-50 column $(0.6 \times 25 \mathrm{~cm})$. It was eluted with a linear gradient from 0 to $95 \%$ acetonitrile in $0.05 \%$ trifluoroacetic acid (TFA). ACE inhibitory activity passed through the column. The final ACE inhibitor from Ashitaba was purified about 300 -fold.

The mass spectrum of the final preparation was measured on a Kompact MALDI-4 (Shimadzu Co., Ltd.). 2,5-Dihydroxybenzoic acid (DHBA) was used as the matrix. The mass spectrum indicated ion peaks $[\mathrm{M}+\mathrm{H}]^{+}(m / z 304),[\mathrm{M}+\mathrm{Na}]^{+}$ $(m / z 326)$ and $[\mathrm{M}+2 \mathrm{Na}]^{+}(m / z$ 348). Nicotianamine from tobacco leaves $(12)$ reported to be a molecular weight of 303 , and nicotianamine from Japanese soy 
sauces (7) was also reported to have ACE inhibitory activity. Nicotianamine has carboxylic groups. The present mass spectrum shows those two Na-salt forms. It was suggested that the ACE inhibitory fraction from Ashitaba contained nicotianamine.

The final ACE inhibitor was investigated by TLC with solvents of $n$ propanol-pyridine-acetic acid-water $(2: 1: 1: 1, \mathrm{v} / \mathrm{v})$ and $n$-propanol-29\% ammonia solution $(7: 3, \mathrm{v} / \mathrm{v})$. Both locations of the ACE inhibitor and nicotianamine coincided as shown in Fig. 3, I and II. Another TLC with a solvent of butanol-methanol-water $(2: 1: 1, \mathrm{v} / \mathrm{v})$ was done and ACE inhibitory activity assayed (Fig. 3III). The spots of the ACE inhibitor and nicotianamine indicated the same location (Fig. 3III, left) and had ACE inhibitory activity (Fig. 3III, right). These results suggest that the ACE inhibitor from Ashitaba was very similar to nicotianamine. The $\mathrm{IC}_{50}$ value of the final purified ACE inhibitor was estimated to be about $1.1 \mu \mathrm{g} / \mathrm{mL}$, which was the same value as that of nicotianamine presented by Kinoshita et al (7).

Kinoshita et al (Kikkoman Co., Ltd.) have reported, the ACE inhibitory activity of nicotianamine and the effect of a single oral administration in SHR (7). We also investigated the effects of the ACE inhibitory fraction from Ashitaba on hypertensive rats over long-term administration. These effects further confirmed the experiment of a single oral administration to SHR. Nicotianamine was reported by Noma and Noguchi (12) from tobacco leaves and by Kristensen and Larsen (13) from seeds. Budesinsky et al $(14,15)$ have reported the presence of nicotianamine in Leguminosae and isolated it from the aerial parts of alfalfa (Medicago sativa $\mathrm{L}$ ). Nicotianamine has an optimal molecular structure for chelating irons, and was considered to be a possible phytosiderophore with an essential function in cellular iron transport and metabolism. Nicotianamine might be a representative inhibitor of ACE because of a powerful chelating action. In addition, the 2-carboxylic acid present in the structure of nicotianamine must be rendered for ACE inhibition. There is one patent application claiming production by a microorganism (Basidiobolus sp) $(16,17)$.

In recent years, several ACE inhibitory peptides were isolated and identified from food materials (2-4), and some inhibitors of this enzyme showed antihypertensive effects in vivo (18-23). However, most of them were peptides of enzymatic hydrolysates from food protein sources. Non-peptidyl ACE inhibitory substances have been reported $(9,24,25)$. The present ACE inhibitor from Ashitaba may also be a non-peptidyl molecule.

Ashitaba has been said to have a good effect on human health. It contains dietary fiber, potassium, etc., and must have great efficacy in blood pressure in a living body. In this study, we found that the ACE inhibitor from Ashitaba contributed to the control of blood pressure. We need to conduct more experiments to clarify the detailed mechanism of the effects in vivo. 

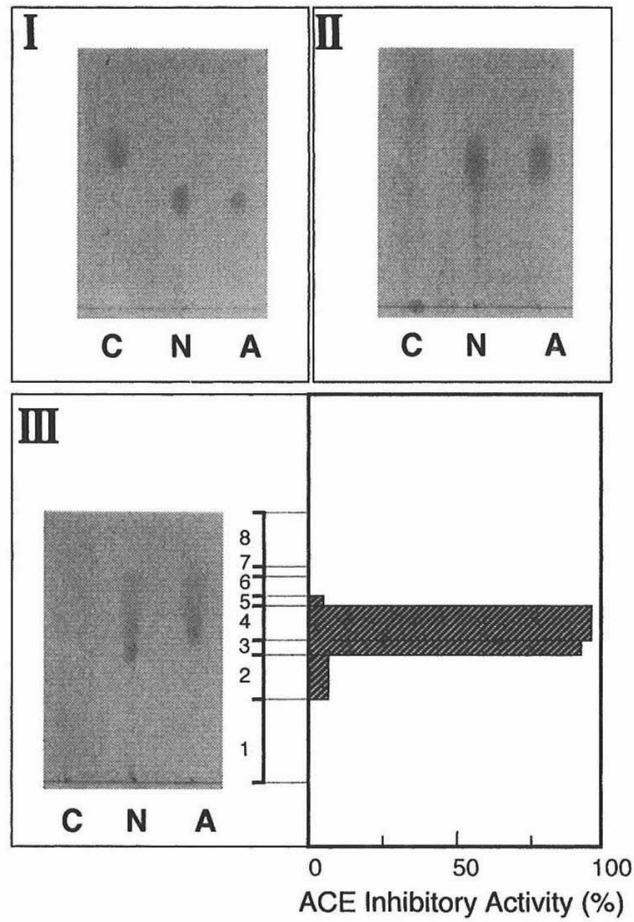

Fig. 3. Thin-layer chromatograms of the ACE inhibitor on silica-gel. Three kinds of developing solvents were used as follows: I, $n$-propanol-ammonia solution $(7: 3, \mathrm{v} / \mathrm{v})$; II, n-propanol-pyridine-acetic acid-water $(2: 1: 1: 1, \mathrm{v} / \mathrm{v})$; and III, butanolmethanol-water $(2: 1: 1, \mathrm{v} / \mathrm{v})$. In III, ACE inhibitory activity is shown on the right side. The ACE inhibitors from Ashitaba, nicotianamine and cystine were detected by spraying $0.2 \%$ ninhydrín-butanol. C, cystine; $\mathrm{N}$, nicotianamine; $\mathrm{A}, \mathrm{ACE}$ inhibitor from Ashitaba.

We are very grateful to Ms. E. Kiņoshita, Kikkoman Co., for presenting authentic nicotianamine. We thank Ms. M. Sunaga for providing technical assistance.

\section{REFERENCES}

1) Dzau VJ. 1988. Circulating versus local renin-angiotensin system in cardiovascular homeostasis. Circulation 77: 4-13.

2) Gary AF, French FJ, Dage CR. 1995. Dual inhibitors of ACE and neutral endopeptidase. In: Hypertensions (Laragh JH, Brenner BM, eds), 2nd ed, p 3099-3112. Raven Press, N.Y.

3) Maruyama S, Suzuki H. 1982. A peptide inhibitor of angiotensin I-converting enzyme in the tryptic hydrolysate of casein. Agric Biol Chem 46: 1393-1394.

4) Kohama Y, Matsumoto S, Oka H, Teramoto T, Okabe M, Mimura T. 1988. Isolation of angiotensin-converting enzyme inhibitor from tuna muscle. Biochem Biophys Res

Vol 45, No 3, 1999 
Commun 155: 322-337.

5) Matsui T, Matsufuji H, Seki E, Osajima K, Nakashima M, Osajima Y. 1993. Inhibition of angiotensin I-converting enzyme. Biosci Biotechnol Biochem 57: 922-925.

6) Horie H, Goto T, Kohata K. 1996. Comparison of inhibitory activity of angiotensin I-converting enzyme among various kinds of teas. Bull Tea Proc Technol, 9: 37-40.

7) Kinoshita E, Yamakoshi J, Kikuchi M. 1993. Purification and identification of an angiotensin I-converting enzyme inhibitor from soy sauce. Biosci Biotechnol Biochem 57: $1107-1110$.

8) Monma K, Kikutani N, Kasahara T, Iguchi M, Tomomatu T, Murakami Y, Urano M. 1990. Proximate and mineral composition of Ashitaba (Angelica keiskei) harvested in the Izu Islands. Ann Rep Tokyo Metr Res Lab 41: 158-161.

9) Murakami M, Kijima H, Muramatsu Y, Aihara H, Otomo S, Baba K, Kozawa M. 1989. Inhibition of gastric H, K-ATPase by chalcone derivatives, xanthoangelol and 4-hydroxyderricin, from Angelica keiskei Koizumi. J Pharm Pharmacol 42: 723-726.

10) Yagi A. 1989. Chemical and pharmacological studies on Angelica keiskei. Bull Hukuyama Univ 7: 1-23.

11) Cushman DW, Cheung HS. 1971. Spectrophotometric assay and properties of the angiotensin-converting enzyme of rabbit lung. Biochem Pharmacol 20: 1673-1648.

12) Noma M, Noguchi M. 1971. A new amino acid, nicotianamine, from tabacco leaves. Tetrahedron Lett 22: 2017-2020.

13) Kristensen IB, Larsen PO. 1974. Azetidene-2-carboxylic acid derivatives from seeds of Fagus silvatica L. and a revised structure for nicotianamine. Phytochemistry 13: 2791-2798.

14) Budesinsky M, Budzikiewicz H, Prochazka Z, Ripprtger H, Romer A, Scholz G, Schreiber K. 1980. Nicotianamine, a possible phytosiderophore of general occurrence. Phytochemistry 19: 2295-2297.

15) Budesinsky M, Prochazka Z, Budzikiewicz H, Romer A, Ripprtger H, Schreiber K, Scholz G. 1981. On the normalizing factor for the tomato mutant chloronerva. XI. mass and NMR spectroscopic investigations of the phytosiderophore nicotianamine and some of its derivatives. Pflanzen 37: 191-196.

16) Mikami Y, Suzuki T. 1983. Novel microbial inhibitors of angiotensin-converting enzyme, aspergillomarasmines A and B. Agric Biol Chem 47: 2693-2695.

17) Rudolph A, Becker R, Sholz G, Prochazka Z, Toman J, Macek T, Heront V. 1985. The occurrence of the amino acid nicotianamine in plants and microorganisms. A reinvestigation. Biochem Physiol Pflanzen 180: 557-563.

18) Maruyama S, Mitachi H, Tanaka H, Tomizuka N, Suzuki H. 1987. Studies on the active site and antihypertensive activity of angiotensin I-converting enzyme inhibitors derived from casein. Agric Biol Chem 51: 1581-1586.

19) Fujii M, Matsumura N, Mito K, Shimizu T, Kuwahara M, Sugano S, Karaki H. 1993. Antihypertensive effects of peptides in autolysate of bonito bowels on spontaneously hypertensive rats. Biosci Biotechnol Biochem 57: 2186-2188.

20) Yokoyama K, Fujita H, Yasumoto R, Yoshikawa M. 1993. Peptide inhibitors for angiotensin I-converting enzyme derived from food proteins. Pep Chem 1992: 420-423.

21) Wako Y, Ishikawa S, Muramoto K. 1996. Angiotensin I-converting enzyme in autolysates of squid liver and mantle muscle. Biosci Biotechnol Biochem 60: 1353-1355.

22) Karaki H, Doi K, Sugano S, Uchiwa H, Sugái R, Murakami U, Takemoto S. 1990. Antihypertensive effect of tryptic hydrolysate of milk casein in spontaneously hypertensive rats. Comp Biochem Physiol 96C: 367-371. 
23) Sugiyama K, Takada K, Egawa M, Yamamoto I. 1991. Hypotensive effect of fish protein hydrolysate. Nippon Nogeikagaku Kaishi 65: 35-43.

24) Saito Y, Nakamura K, Kawato A, Imayasu S. 1992. Angiotensin I-converting enzyme inhibitors in sake and its by-products. Nippon Nogeikagaku Kaishi 66: 1081-1087.

25) Hara Y, Matsuzaki T, Suzuki T. 1987. Angiotensin I-converting enzyme inhibiting activity of tea components. Nippon Nogeikagaku Kaishi 61: 803-808. 